\title{
SHRINK TO EXPAND: \\ THE READYMADES THROUGH THE LARGE GLASS
}

\section{Jacob Wamberg}

\begin{abstract}
Departing from Duchamp's advice in 1961 of finding the "common factor" between the non-representative and the representative, translated here into modernism and avant-garde, this article seeks to understand the readymades as objects that have passed metaphorically through Duchamp's magnum opus, the unfinished Large Glass (1915-23). More precisely, the readymades are seen as mass-produced utensils that have been stripped bare of their usual function, i.e. their actualization, in order to regain potentiality. Mapping Giorgio Agamben's interpretation of Herman Melville's short story Bartleby, the Scrivener (1856) onto the readymades, this shrink-to-expand strategy is understood as a skeptical suspension of judgment, epoché, comparable to Bartleby's polite refusal to work. Moreover, it is seen as equivalent to the down-scaling of dimensionality observed in the Large Glass, where transparency in one go eliminates the representation of spatial circumstances and opens up the objects toward the ever-changing physical surroundings, thereby exposing more of those 4-dimensional projections, which are normally suppressed in our reduced 3-dimensional perception of the world.
\end{abstract}

\section{KEYWORDS}

Marcel Duchamp, Epoché, Potentiality, Skepticism, Theory of technology, 4-dimensionality, Alchemy

In his closing address to "Where do we go from here?", a symposium held at the Philadelphia Museum College of Art in March 1961, Marcel Duchamp speculated intriguingly on the future of art. ${ }^{1}$ Remarking that the art market over the previous two decades had fully absorbed the retinal approach peaking in Abstract Expressionism, Duchamp expressed a desire that the "great artist of tomorrow will go underground." Initiating "a revolution on the ascetic level," the artist should resist "a world blinded by economic fireworks." If the ageing artist's dream was soon realized in the emergence of anti-commercial movements such as Fluxus, Arte 
Povera, and Conceptual Art, these were nevertheless deferred actions in Hal Foster's Freudian sense. ${ }^{2}$ As Duchamp reaffirmed in 1964, they would only repeat what he had already performed himself half a century earlier through the ascetic underground revolution par excellence: the introduction in the art world of the readymades. ${ }^{3}$ Still, in spite of all his anti-retinalism, the Duchamp of 1961 would not accept the dilemma of the last hundred years that forced artists to choose between the "representative" (the antiretinal) and the "non-representative" (the retinal). Instead, all the "isms" should be grouped according to what Duchamp termed "their common factor." Like Alice in Wonderland, the artist of tomorrow "will be led to pass through the looking-glass of the retina, to reach a more profound expression."

In this paper, I demonstrate that this Alice in Wonderland gesture had also been performed by the early Duchamp. Although the readymades are often discussed at a certain distance from his unfinished magnum opus from the same time, The Bride Stripped Bare by Her Bachelors, Even (1915-23) (Fig. 3.2), they could be conceived of as industrial gadgets that have passed through this monumental looking-glass. For at the same time as with his readymades, Duchamp cleansed industrial gadgets from their original utilitarian function, thus giving them a wider range of potentiality - what could be described through the skepticist notion of epoché, or suspension of judgment-he also staged a similar purification in the way the Large Glass converts its representational mode into an operational one, the spatial down-scaling of its forms opening up towards a framed embedding in the actual surroundings. The Large Glass thereby appears concretely as a looking-glass, the transparency of which oscillates between iconicity and symbolism, between retinal pictorial screen (modernism) and aura of concepts (avant-garde).

More precisely, the readymades' critique of contemporary mass-produced technology and capitalist work ethics through epoché could be linked to the Glass's notion of stripping bare the Bride, an alchemical transformation through which the Bride's particularized marriage is converted to virginal prima materia. This process of breaking down actualization and upgrading potentiality-a principle I shall call "shrink to expand"-is translated quite explicitly into spatial terms. For the very act of transparency leads to an erasure of all represented particularitiesspatial environments-and therefore also to a down-scaling of dimensionality that in Duchamp's thinking makes the objects more receptive toward the unseen 4-dimensional world. In the Glass, 
this conversion from higher-dimensional appearance to lowerdimensional apparition, and back to strengthened receptiveness of even higher-dimensional re-inscriptions, becomes apparent, since the Glass's space-reducing act of transparency is the same act that opens the objects toward their actual and ever-changing physical surroundings.

What secures this double movement of reduction of actualization and opening towards a widened scope of actualizations is, in the broadest sense, a framing-a framing which in semiological terms is visualized in the so-called "Top Inscription" or "Milky Way," in whose bulging cinematic frames, the "Draft Pistons," the Bride appears to her Bachelors. These photographic freezings, a conceptually determined epoché, again find an echo in Duchamp's speculations of the readymades as semiologically framed 3-dimensional photographs-just as the readymades are often presented in ways that stress their status as lower-dimensional projections, or apparitions, that mediate between different dimensions like their siblings in the Large Glass.

\section{RETINAL/ANTI-RETINAL}

What I see as truly remarkable in Duchamp's late statements of 1961 is his consolatory attitude to his often formulated antagonism of retinal and anti-retinal. While noting that the problematic nineteenth-century liberation of the artist as an individual 'gave birth to all the 'isms' which have followed one another during the last century at the rate of one new 'ism' about every fifteen years"-that is, primarily the retinal pathDuchamp nevertheless suggested that "we must group the 'isms' together through their common factor, instead of differentiating them," including Surrealism, which actually "reduced the role of the retina to that of an open window on the phenomena of the brain." It is hereby that we could overcome the divide between the "representative" and the "non-representative" and, like Alice in Wonderland, "pass through the looking-glass of the retina to reach a more profound expression.”

For a contemporary reader, it could be tempting to collapse the "representative" with representation pure and simple and thereby with just a more figurative version of the retinal sphere. But this would clearly be a misunderstanding. Duchamp's remark on Surrealism shows why. To use a term from Speculative Realism, we could say that for him the "representative" in Surrealism concerns something object oriented that reduces the pleasure, or the sensuous friction of the retinal, to such a degree that it makes sense 
to link it to the anti-retinal, thus rather turning "representative" into what today is typically termed "presentative." Surrealism's "open windows" hereby become compatible with those conceptual frames or auras with which Duchamp encapsulated or bracketed off outer material objects in his own readymades.

Moreover, I suggest mapping the correlation of the two antagonisms, representative/non-representative and anti-retinal/ retinal, onto the avant-garde/modernism dualism implied by Peter Bürger. This dualism, however, was only given full verbal formulation by his exegete, Jochen Schulte-Sasse, when in the introduction (1984) to the English translation of Bürger's seminal book, Theorie der Avantgarde (1974), Schulte-Sasse interpreted Bürger's heritage of aestheticism as a distinct trend: modernism. This contemplative practice was thus isolated from an intervention into life practice performed by the avant-gardes according to Bürger. ${ }^{4}$ In a diagrammatic overview we have:

\author{
Retinal / Anti-retinal \\ Anti-representative / Representative (or: presentative) \\ Modernism / Avant-garde
}

An initial key to overcoming these dualisms, once correlated, is to view the left row as particularly opaque variations of the notion of "looking-glass:" a "window" that attracts so much attention to its own retinal friction that it should be considered more a "screen" or even a "mirror." Such a retinal screen is more or less abstract and would therefore peak in modernist movements such as Abstract Expressionism. However, if we lessen the opacity of the screen and direct the attention to the objects mediated through it we move towards the right row of the Avant-garde, converting the lookingglass first to a transparent window (Surrealism) and later to frames or auras of semiological signs (conceptualism). In the right row, more or less material objects are thus presented inside diverging frames, from the ones explicitly mediating representation to the ones implicitly mediating concepts.

\title{
EPOCHÉ
}

But if a "common factor" between retinal modernism and antiretinal avant-garde could be found in the frame, a device that mediates between perceptualist screens and conceptualist auras, it remains, nevertheless, a necessary but not sufficient condition. For a prime characteristic of modernism is the visual indeterminacy of the objects shown: their abstraction. This interpretative 
indeterminacy should therefore also be transferred to the conceptual register of interpretation when, passing through the looking-glass and ending in the right row of the avant-garde, the objects, processes, or events become more physically present and accordingly more visually accessible. We are thus looking for a notion of indeterminacy that would be a "common factor" between retinal abstraction and anti-retinal conceptual avant-garde.

Appropriating ideas from Giorgio Agamben, I suggest that such a key concept may be provided by the ancient Greek notion of epoché, suspension of judgment (literally "holding back"). Counteracting a civilization that has degenerated into overdifferentiated perceptions and habits, including technological functions, epoché could be seen as a pervasive strategy for modernist and avant-garde art that offers evolutionary refreshment, reestablishing lost potentialities amidst specialized actualizations by blocking perceptions or habits of action, including technological affordances. Modernist retinal abstraction could thus be described as perceptual epoché (I don't know what I see), avant-garde antiretinal matter-orientation as functional epoché (I don't know what the goal of this or that object, process, event, or even already mediated phenomenon is).

Art history has hitherto been mostly concerned with seeing the readymades from inside the art world and thereby, given the art world's focus on perception, as a limiting case of what I term perceptual epoché. Frustrating the retinal sphere to the point where the perceptual screen is converted into a conceptual frame or aura-Kantian disinterest having hereby been transformed into Duchampian indifference-the readymades become primal cases for contemplating the function of artworks as art. In Thierry de Duve's neo-Kantian understanding, the readymades shift the attention of aesthetic judgment from the question of what makes this object beautiful to what makes this object a work of art. ${ }^{5}$ Not dismissing in any way this ultimately modernist angle, I will here supplement the conceptual superstructure of perceptual epoché with its sibling: the conceptual superstructure of functional epoché. Through withholding or bracketing their usual utilitarian functionthat is, their usual technological relation to the interacting bodythe readymades not only ask what makes this object useful in its pre-ordained function (cp. the aesthetic question of what makes this object beautiful) but pose the general question of what makes this object a utensil at all (cp. the aesthetic question of what makes this object a work of art). Thus, by regaining their utilitarian potential, the readymades live up to Bürger's idea of avant-garde art as an 
actual transformation of life practice. While implying a shift of accent from modernism to avant-garde, this also implies a shift of analytical lens from the theory of art to the theory of technology.

Introducing the readymades, objects that hover indeterminately between art and utilitarian technology and thus frustrate both perception and function in an ambiguous suspension of judgment, Duchamp became a pioneer in expanding the notion of epoché in art. If the combined functional and perceptual epoché of Duchamp's readymades challenged viewers by subverting conventions in a mingling of perceptual and utilitarian domains, this subversive conceptual framework holds a potential to break up any inherited habits. To be sure, the mildly ironic epoché of Duchamp, and of conceptual art much later, would appear quite different from the more concretely intervening negation of, for instance, Cubist or Futurist splintering of the human body, or wilder forms of Dada turmoil. Nevertheless, even such negating forms of modernism and avant-garde are surrounded by an outer aura of interpretative indeterminacy that could still be designated as epoché.

Reintroduced in the twentieth-century philosophy by the phenomenologist Edmund Husserl, the notion of epoché derives from ancient skepticism and its protagonist Pyrrho from Elis. As American critic Thomas McEvilley remarked shrewdly in 1988, this Hellenistic philosopher had a pervasive resonance for Duchamp, although Duchamp only mentioned him once. 6 Duchamp's monographer Arturo Schwarz remarks:

Reading the manuscript of the first edition of this book, Duchamp recalled in a conversation with the author that when he had been a librarian at the Bibliothèque Sainte-Geneviève in Paris, he had gone through the works of the Greek philosophers and found that he most appreciated the attitude of Pyrrho and the skeptics as being closest to his own. ${ }^{7}$

Like Duchamp, Pyrrho was originally a painter who gave up retinalism, in his case moving to pure philosophy. Like Duchamp too, he wanted to practice a life of independence, always being indifferent and not giving over to emotions. According to his Greek biographer, the third-century AD writer Diogenes Laertius, Pyrrho claimed that it "was a difficult thing entirely to put off humanity; but that a man ought to strive with all his power to counteract circumstances with his actions if possible, and at all events with his reason." 8 For Pyrrho stated that everything we know is a result of customs and laws and nothing in our senses is to be trusted. 
The same object will present itself differently to different senses and under different circumstances, and objects are only known in relation to other objects and shift character according to varying relations. ${ }^{9}$ This is in close correspondence with Duchamp's skeptical attitude towards science and epistemology—as he stated:

Maybe it's all just an illusion. We are so fond of ourselves, we think we are little gods of the earth-I have my doubts about it, that's all. The word 'law' is against my principles. [...] I just didn't see why we should have such reverence for science, and so I had to give another sort of pseudo explanation. I'm pseudo all in all, that's my characteristic. I never could stand the seriousness of life, but when the serious is tinted with humor it makes a nicer color. ${ }^{10}$

Anticipating Duchamp's overturning of science with its own means, the skeptics wanted similarly to overturn reason through reason, so that "if we assert that there is no such thing as space, we must employ the word 'space,' but that not dogmatically, but demonstratively [...]." 11

All this was summed up in epoché, the key concept for the investigatory attitude of the skeptics. Through suspending judgment, the skeptics doubted everything and abstained from making positive statements: "Not more one thing than another" (the Greek Ou mallon). ${ }^{12}$ This same attitude of indifference is pervasive in Duchamp who, for instance, in a late interview with Francis Roberts, occasioned by his first retrospective in Pasadena in 1963, claimed: "No, no the word 'anti' annoys me a little, because whether you are anti or for, it's two sides of the same thing. And I would like to be completely-I don't know what you say-nonexistent, instead of being for or against [...]." 13 The readymades could thus be seen as agents for this nonexistence, the attitude of being neither for nor against. Recalling Duchamp's declaration of himself as an Anartist, the Mexican author and later Nobel laureate Octavio Paz appositely remarks: "The Readymades are not anti-art, like so many modern creations, but rather an-artistic. Neither art nor antiart, but something in between, indifferent, existing in a void.”14

A striking parallel, if not direct source of this indifference, of being neither for nor against, is found in Herman Melville's short story from 1853, Bartleby, The Scrivener: A Story of Wall-Street. ${ }^{15}$ Frustrated by his unstable copyists, a Wall Street lawyer employs a new scribe, Bartleby, who initially proves satisfactory but then one day suddenly declines to work, claiming repeatedly but with utmost 
politeness, “I would prefer not to.” Giving up work, Bartleby enters a sort of limbo in which he just exists: first writing a little, then staring at the wall, and, finally, now in prison, giving up eating and dying from starvation. The lawyer who tells the story is mystified by this behavior but sees it as a sort of "passive resistance." This resistance includes giving up particularity, since three times Bartley claims, "I am not particular.” It even implies giving up his human feelings: the lawyer notes in Bartleby a striking absence of "uneasiness, anger, impatience or impertinence [...] in other words [...] any thing ordinarily human.” When the last sentence of the story laments, "Ah Bartleby! Ah humanity!", it is troublingly indeterminate whether it is specific to this particular loss of humanity or rather to humanity itself with its senseless work addiction.

I claim that Duchamp and his outer agents, the readymades, have entered the same indifferent state as Bartleby. How radically Duchamp fled any fixed identity was stressed by his friend Robert Lebel: "Nothing characterizes him better [...] than his repugnance toward solidifying in a single tendency, a single conviction, a single technique, in a single country, a single milieu, or even a single identity and a single sex, as his feminine pseudonym Rrose Sélavy testifies.” 16 In Giorgio Agamben's reading of Melville's story, this inhuman state of nonexistence, of being neither for nor against, in which particularized feelings are absent, is indeed equivalent to the skeptical epoché, in which things are ou mallon: no more this than that. In Aristotelean terms, this amounts to withholding or taking back actualization in order to maximize potentiality, to reach the tabula rasa, the tiny undescribed wax tablet, in which thought (nous) thinks itself and may turn into anything-including the potentiality of not thinking anything at all. In this glistening aura of the possible, thought hovers between yes and no, being and nothingness, cognition and sensation, word and thing.

Supplementing Agamben with a contemporary metaphor from biotechnology, we could compare epoché to the procedure of breaking down the specialization of a bodily cell, re-creating the stem cell, which could turn into anything or nothing at all. In Agamben's reading of Bartleby, the scrivener's abandonment of scripture moves beyond the first creation, the monotheistic creation ex nihilo, into the second creation

in which God summons all his potential not to be, creating on the basis of a point of indifference between potentiality and impotentiality. The creation that is now fulfilled is neither a recreation nor an eternal repetition; it is rather, a decreation in 
which what happened and what did not happen are returned to their originary unity in the mind of God, while what could not have been but was becomes indistinguishable from what could have been but was not. ${ }^{17}$

Translating this passage from religious into artistic creation, we could compare the first creation, the creation from nothing, with modernism's ideal of original invention, and the second creation, God's summoning of all his potential not to be, with Duchamp's decreation through the readymades. Breaking downthe actualization of already created objects, Duchamp returns them to their original potential. Agamben's notion of decreation, the state in which "what could not have been but was becomes indistinguishable from what could have been but was not," especially recalls Duchamp's speculations on the "art co-efficient" - the gap between the artist's intention and the realization: "In other words, the personal 'art coefficient' is like an arithmetical relation between the unexpressed but intended and the unintentionally expressed." 18 For Duchamp, art objects are no different from other objects in not possessing a full actualization of their potentiality, which is not even known to the artist and, therefore, has to be re-interpreted or actualized anew by every new spectator.

Although Agamben does not refer to Duchamp in his Melville reading, Duchamp is included in a whole horde of Bartleby siblings in the splendid short novel Bartleby \& Co. from 2000 by the Spanish author Enrique Vila-Matas. ${ }^{19}$ The common factor of these siblings, real or invented-from Melville himself to Hölderlin, from Balzac's Frenhofer to Musil's Man without Qualities, to Beckett's Watt-is a strange paralysis in relation to artistic creation: a pervasive "I prefer not to.”

\section{THE LENS OF THEORY OF TECHNOLOGY}

To explore more profoundly what this Bartleby-Duchamp correlation means, we should shift our lens from the theory of art to that of work and technology-or rather overlap these lenses. As has recently been discussed by the Italian Marxist philosopher Maurizio Lazzarato, Duchamp, like Bartleby, explicitly detested the capitalist work ethic in which you have to work and barter work in order to live. "Who made all those little rules that dictate you won't get food if you don't show signs of activity or production of some kind?", Duchamp asked in an interview with Calvin Tomkins in 1964, pointing instead to The Right to Be Lazy, a book from 1883 by Marx' son-in-law, the French revolutionary socialist Paul 
Lafargue. ${ }^{20}$ From the perspective of work, the readymades as automated products violate that veneration of handicraft that had given artworks a new raison d'être in competition with emerging industrialism. But the readymades also disrupt the utilitarian goals that allegedly made factory work meaningful.

If we bring our lens more specifically toward technology, we can see Duchamp's shift from painting to the world of the readymades and the Large Glass from 1913 onwards as a troubled reaction to the contemporary rise of natural sciences and their respective offshoots in machinic technology and design. Take the crucial anecdote of Duchamp visiting the Parisian aeroplane exhibition, Salon de l'Aviation, with Constantin Brancusi and Fernand Léger in October 1912. As recalled by Léger in the mid-50s, Duchamp, a dry type with something elusive about him, circled around the motors and propellers without saying a word. Suddenly, he turned towards Brancusi and exclaimed "It's finished, painting. Who can do anything better than this propeller. Tell me, can you do that?” 21

Similar admiration for technology mixed with disillusionment for art were exposed when Duchamp landed in his new adopted home country, USA, in the summer of 1915. In the interviews from September 1915 with American journalists, who were curious to meet the man behind the sensation of the Armory Show in 1913, Nude Descending a Staircase (1912) (Cp. Fig. 4.1), Duchamp says, "If only America would realize that the art of Europe is finisheddead-and that America is the country of the art of the future [...]. Look at the skyscrapers! Does Europe have anything more beautiful to show than these?" He states further, "New York is itself a work of art, a complex work of art [...]. And I believe that the idea of destructing old buildings, old souvenirs, is quite alright.” 22 Duchamp's friend Beatrice Wood expresses a similar attitude in her editorial in the second issue of The Blind Man from May 1917 (Fig. 1.3). In the little journal with the very anti-retinal title that treated Fountain's rejection at the exhibition of the Society of Independent Artists a month before, she posits that "The only works of art America has given are her plumbing and her bridges.”

The point, however, is that in spite of Duchamp's technological fascination, he in no way accepted technology as it was. His attitude toward technology and science, and the whole capitalist apparatus that sustained both through a pervasive Protestant work ethic, was one of 'if you can't beat them, join them!' Nevertheless, the move from old-fashioned art (retinal perception) and joining the party of technology (anti-retinal use) happened through a Trojan horse: the skeptical strategy of breaking down reason with reason, technology 
with technology. Duchamp described this mild sabotage from within through the withdrawal of judgment, in other words, epoché:

I was interested in introducing the precise and exact aspect of science, which hadn't often been done, or at least hadn't been talked about very much. It wasn't for love of science that I did this; on the contrary, it was rather in order to discredit it, mildly, lightly, unimportantly. But the irony was present. ${ }^{23}$

It is hardly a coincidence that Fountain (Fig. 1.8) is an excellent piece of that plumbing which, together with bridges and skyscrapers, were declared by Duchamp to be America's sole contribution to art. In a note, Duchamp even bluntly proposes to convert the newly finished Woolworth Building, the then highest Manhattan skyscraper, into a readymade, thus opening the path toward Christo's much later building wrappings. ${ }^{24}$ Alongside Agamben and Aristotle, we could say that by exposing industrially produced objects to epoché and transposing them to the non-functional world of art, Duchamp engaged in an act of decreation. He halted their usual function and actualization in order to regenerate, or reboot, their potentiality in their new appearance as readymades. We could term this procedure of epoché as "shrink to expand:" shrink actualization in order to expand potentiality-towards a widened field of new possible actualizations. As The Blind Man editorial specifies, "He [Mr. Mutt] took an ordinary article from life, placed it so that its useful significance disappeared under the new title and point of viewcreated a new thought for that object."

This new thought opens the whole extended sphere of potentiality that may be realized in countless new ways. As Louise Norton further specifies in The Blind Man, with unmistakable reference to Duchampian projects, a key source for the idea of such a new thought is the symbolist writer Remy de Gourmont's essay "La dissociation des idées" (1900). ${ }^{25}$ Here, the most intelligent, most difficult creative act is described not as putting ideas together anew, but rather as splitting up old ones; a decreation, mocking, in Norton's words, "how sacred is the marriage of ideas.” According to Norton's examples of this marriage between ideas and real life, even a married man is not only a husband bound to one woman and, in his job, a "money-making device;" he may be "some other woman's very personification of her abstract idea.” By dissociating the usual marriage of ideas to certain objects, Fountain has thus widened this multivalence, the potentiality of concepts in relation to the entities they designate, and has thereby extended its own 
functional, perceptual, and conceptual scope. That a urinal should be a fitting object for breaking up traditional marriage bonds was already signaled by one of the notes in the Box of 1914, "- -one only has: for female the public urinal and one lives by it-.” 26 Isolating a urinal, the signifier for the female organ, from its usual contextand male content-is also loosening it from the marital bonds in accordance with which males allegedly lived. As is emphasized by its outer bulging rim that both connotes the folds of the female organ and an aura of concepts, Fountain exemplifies beautifully Duchamp's statement from the late 1950s: "I want to grasp things with the mind the way the penis is grasped by the vagina." 27

This symbolism, substituting phallic significance with female source, obtains further resonance with the composite aureoles surrounding the knights in Marsden Hartley's eclectic phantasy on copper The Warriors (1913), which forms the backdrop for Fountain in Alfred Stieglitz's photograph of it. ${ }^{28}$ Hartley, a highly valued protégé of Stieglitz who lived out his both queer and pro-militant tendencies in Berlin 1913-14, was often paradoxically playing with vagina-alluding aureoles and mandorlas, sometimes with Buddha figures inserted. As a result, Fountain partakes in an androgynous force field converting masculine to feminine aureole, ultimately turning "Buddha of the Bathroom," The Blind Man's designation for Fountain, into a Virgin. ${ }^{29}$

If the displacement of the readymades to the exhibition context of the art world contributes significantly to the breaking of marital bonds between ideas and things, conceptual vaginas and material penises, this shaking up of actualization and regaining of potentiality is also assisted through a row of mild sabotage actions: turning around the urinal so it will offer back its waste (stressed in the title Fountain); fastening the bicycle wheel on a stool so you can no longer sit on it-at the same time as the wheel, freed from its tire, rotates eternally to no use, like in a masturbation, according to Duchamp (Fig. 5.4); banging the coat hanger into the floor so you will stumble over it (stressed in the title Trébuchet, Trap) (Fig. 5.1); hanging the hat rack from the ceiling so you cannot reach it (Fig. 5.5); linking the snow shovel to predictions of how it will harm you while in use (stressed in the title In Advance of the Broken Arm) (Fig. 5.2). The only readymades whose former use are seemingly not physically neutralized are the Bottle Dryer (Fig. 6.2) and the Comb (Fig. 5.3), both however originally inscribed with cryptic sentences securing the mutation of the context (the authentic one on the Comb being still in place).

One highly likely source for this sabotage is Alfred Jarry's futuristic novel from 1902, Le Surmâle, whose Proto-Surrealist 


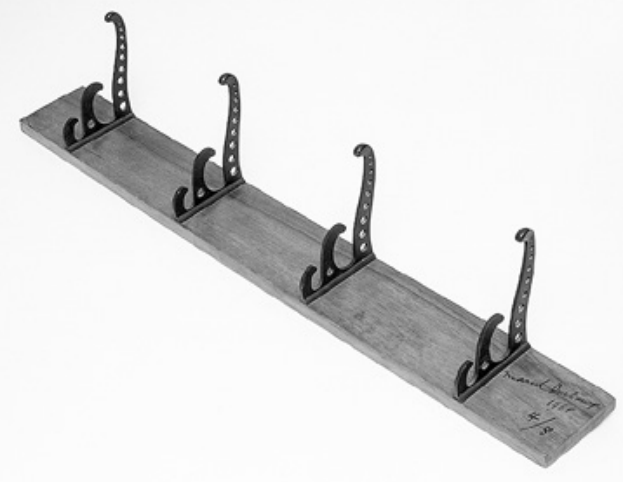

Fig. 5.1

Marcel Duchamp, Trap, 1917/1964. Readymade, Schwerin, Staatliches Museum Schwerin. Photo: Gabriele Broecker @ 2018 Photo Scala, Florence/bpk, Bildagentur fuer Kunst, Kultur und Geschichte, Berlin.

Fig. 5.2

Marcel Duchamp, In Advance of the Broken Arm, 1964 (fourth version, after

lost original of November 1915). Wood and galvanized-iron snow shovel, $132 \mathrm{~cm}$

high. New York, Museum of Modern Art (MoMA). Gift of The Jerry and Emily Spiegel

Family Foundation. $\odot 2018$ Digital image, The Museum of Modern Art, New York

IScala, Florence. 


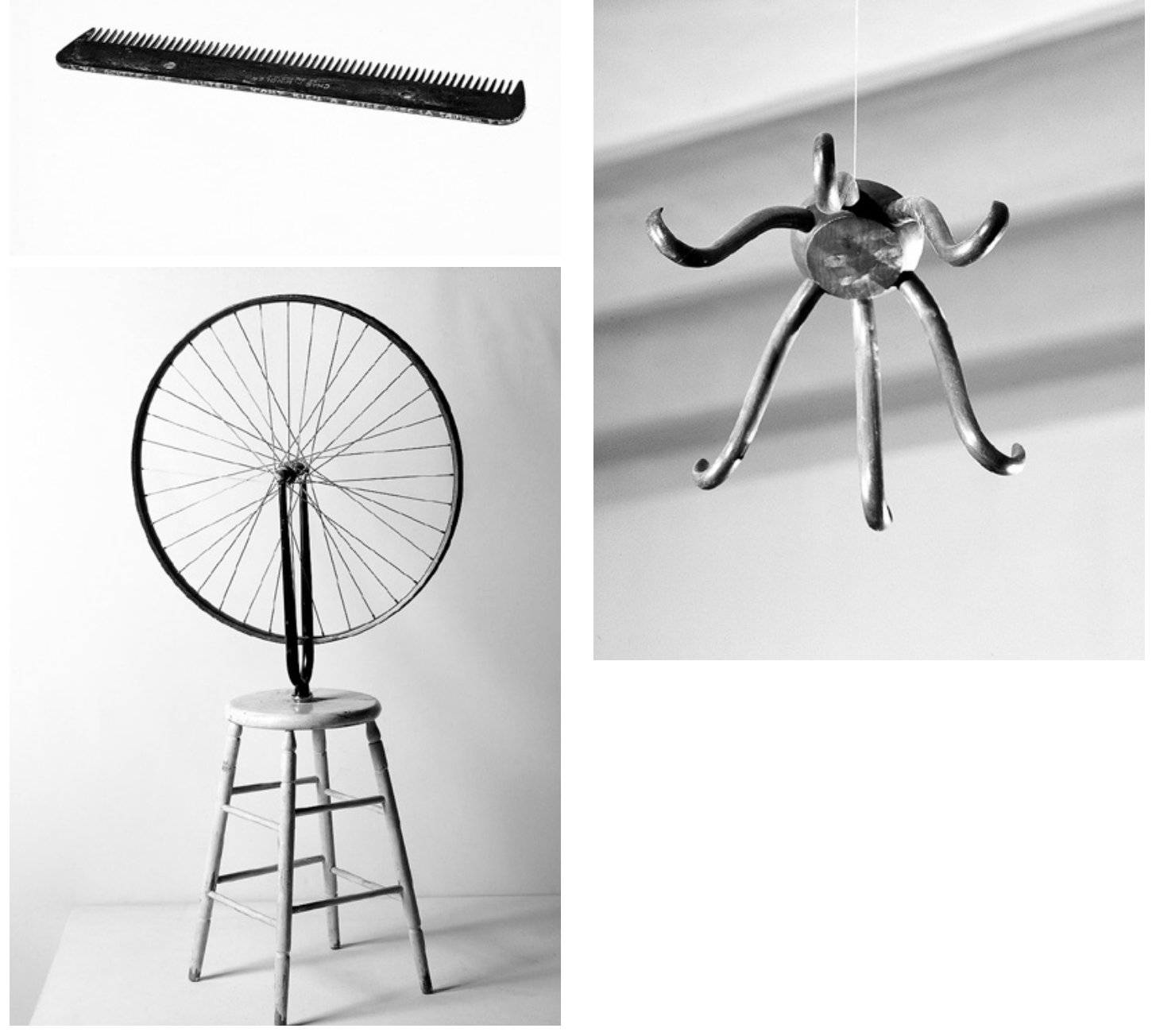

Fig. 5.3

Marcel Duchamp, Comb, 1916. Steel, $3.2 \times 16.5 \mathrm{~cm}$. Philadelphia Museum of Art,

The Louise and Walter Arensberg Collection, 1950. @ 2018. Photo: The Philadelphia

Museum of Art/Art Resource/Scala, Florence.

Fig. 5.4

Marcel Duchamp, Bicycle Wheel, 1913, later replica. Readymade, $126,5 \mathrm{~cm}$. Private collection.

() 2018. White Images/Scala, Florence.

\section{Fig. 5.5}

Marcel Duchamp, Hat Rack, 1917, later replica. Readymade. Private collection. (๑ 2018 White Images/Scala, Florence. 
and indeed early posthuman exploration of machinic sexuality pervades the Large Glass and also offers ideas for other works by Duchamp. In a way that is typical of the novel's mingling of machines and human bodies, a certain general remembers all the things he broke in his youth: "[...] when I was reading at the École Polytechnique, I often unhooked shop signs, unscrewed street urinals, stole milk bottles and locked drunks in hallways." 30 And later, when the general asks André Marcueil, the would-be supermale, if he has stopped wrecking urinals, Marcueil answers, "What urinals? But, my dear general, you can't call it a wrecking device, just demonstrating that it isn't strong enough to withstand the use it is designed for!" 31 So by completely dislocating and turning a urinal around, Duchamp has seemingly fulfilled the implied shared wish of The Supermale, that of wrecking a urinal so much that it withstands the use it is designed for. In the formulation of The Blind Man, this exactly amounts to making the urinal's useful significance disappear and creating a new thought for that object. Hereby, the urinal becomes the most spectacular of The Supermale's broken equipment and disrupted bodies, all pointing towards readymades as regenerating potentiality through making utilitarian tools dysfunctional.

Even the seemingly neutral Bottle Dryer posits itself in this disruptive genealogy (Fig. 6.2). Harking back to Jarry's stolen bottles of milk, which here are virtually emptied out over its erectile spikes, the work becomes almost a mirror image of Fountain ${ }^{32}$ The dialectics of milky sperm-like fluidity and dryness that makes both drops and taste evaporate (cp. Égouttoir) is deepened by the fact that its erectile forms resemble a frozen version of one of the physicist A.M. Worthington's $1 / 10,000$ split second photographs of droplets of water landing in milk, published in his widely distributed A Study in Splashes (1908). ${ }^{33}$

When discussing the readymades as mildly sabotaged technology, it is revealing to consider a book that apparently had a profound impact on Duchamp, Paul Gsell's interviews with the sculptor Auguste Rodin (1911). In a way that may remind us of Melville's Bartleby, Rodin criticizes industrialism for resulting in a loss of the love for work:

The workman, feeling a more or less legitimate hostility for his employer, slights his work. Almost all the men of our day seem to regard work as a frightful necessity, as a cursed drudgery, while it ought to be considered as our happiness and our excuse for living. ${ }^{34}$ 


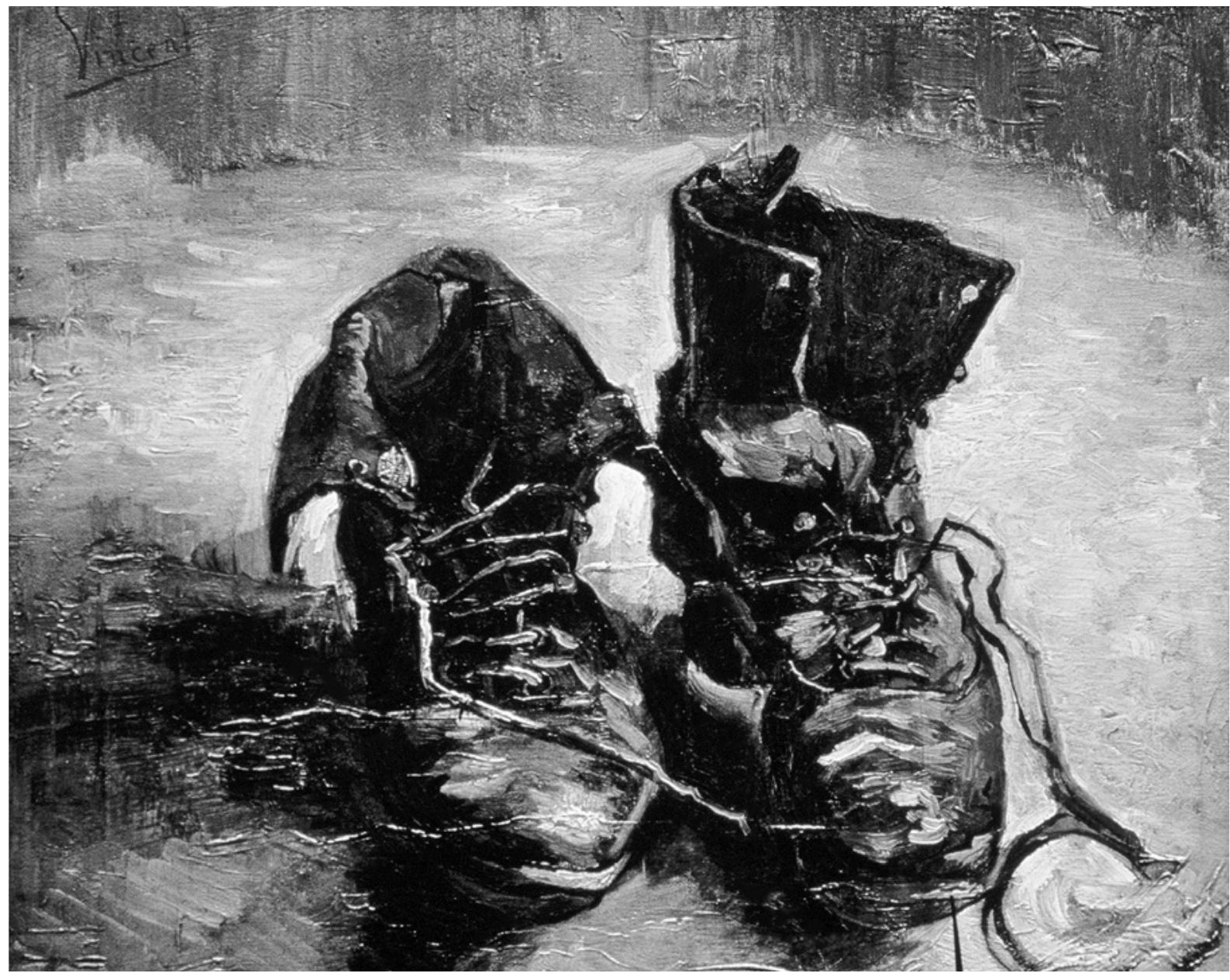

Fig. 5.6

Vincent van Gogh, A pair of shoes, 1886 . Oil on canvas, $38.1 \mathrm{~cm} \times 45.3 \mathrm{~cm}$.

Amsterdam, Van Gogh Museum. ๑ 2018. Photo Art Resource/Scala, Florence. 
In order to change work from a means to existence to its end, Rodin suggests that men follow the example of the artist, "the man who takes pleasure in what he does" [Gsell's emphasis]; "or, better yet, become artists themselves," from carpenters, to masons, to carters; "You see, then, that artists set an example to the rest of the world which might be marvelously fruitful." 35

Isn't it this mission of converting dull work into pleasurable art that Duchamp had set himself with the readymades-transforming drab industrial utensils into something more amusing-and thereby also fulfilling Peter Bürger's notion of avant-garde art as art turned into life practice? In contrast to Rodin's nostalgic view of art as spirited handicraft, however, Duchamp confronts industry openly with its own means, even positively activating what Rodin remarks of his contemporaries: "They only accomplish their task grudgingly. They sabotage it voluntarily.” [Gsell's emphasis] ${ }^{36}$

If we thus consider the readymades as dull industrial artefacts converted into something amusing through being voluntarily sabotaged, it is also surprisingly revealing to consider Martin Heidegger's philosophy of technology. At first glance, the German phenomenological philosopher might not appear as Duchamp's most obvious bedfellow-his self-importance, veneration of rootedness, and ontic seriousness contrasting starkly with Duchamp's self-irony, nomadism, and epistemological skepticism. Nevertheless, Heidegger approaches Duchampian territory in Being and Time (1927), writing that we only become conscious of technology when it fails. In our everyday use of the hammer, when it is ready-at-hand (zuhanden) and feels like an extension of our bodies, we do not give it any special thought. But when the equipment is missing, exerts friction in its use, or breaks down entirely, its being is revealed in a conscious state that approaches but is not identical with that completely distant state of observation that Heidegger describes with the adjective presentat-hand (vorhanden). ${ }^{37}$ The readymades, then, would seem to offer an artificial staging of such a revealing moment of dysfunction. Indeed, like Duchamp, in The Origin of the Work of Art (193536), Heidegger puts forth the idea that art has a special ability to reveal that essence of technology which is hidden in its everyday use. ${ }^{38}$ As is famously demonstrated in his reading of Van Gogh's portrait of a pair of old shoes (Fig. 5.6)—what Heidegger, in his eerie adoration of the Germanic soil, takes as peasants' shoesthis revelation of truth, aletheia, is achieved through an uncanny alienation of the equipment from its everyday use. Although the painting still posits the shoes behind a representative retinal 
screen, Heidegger's lens on it, in its very object orientation, makes almost a pair of readymades out of these shoes.

The difference is, of course, that still being a product of handmade poiesis, these shoes are representatives of an archaic technology, techné, that encompasses both technology and art and whose pre-existing essence can therefore still be revealed in a work of art-in contrast to Duchamp's readymades that are pieces of mass-produced equipment which break down actualization in order to reveal a new potentiality. Equivalently with aesthetic judgment of the readymade moving from the judgment of beauty to the judgment of what makes this object a work of art, teleological judgment of the readymade moves from the judgment of the utilitarian object's pre-given aim to the judgment of what possible aims the readymade might contain.

If we return to Heidegger however, we must observe that, in his postwar thinking, he turns his attention specifically towards industrial technology, the base of which in distant calculation and present-at-handness, makes it an instrument for what Heidegger terms Enframing (Ge-Stell), an abstract scaffolding that posits nature, including the human body, as a passive standing reserve (Bestand) for the insatiable needs of technology. ${ }^{39}$ Moreover, like Rodin, Heidegger thinks that it is only through art that we may break the evil spell of Enframing, finding the saving power in the midst of that which otherwise threatens to destroy us. Since the readymades are exactly the products of such a calculating industry, of which Duchamp is similarly skeptical, their exhibition in revealing dysfunction would seem to offer an example of that saving power, which Heidegger projects into the potential of art. However, whereas Heidegger is still unable to specify how that saving power should be exposed by art in the midst of technology based on Enframing, Duchamp does offer an answer to that question, battling technology, skepticist-wise, with its own means.

\section{ENTERING THE LARGE GLASS}

Having performed this analysis of the readymades as critical interventions in industrial culture, we are better prepared to understand them as entities that have passed through Duchamp's own looking-glass, The Bride Stripped Bare by Her Bachelors, Even (Fig. 3.2). There is certainly a remarkable change of discourse when we move from the readymades to Duchamp's unfinished magnum opus-so much so that Duchamp himself declared in 1966 that "The Readymades are completely different from the Large Glass. 
I made them without any object in view, with no intention other than unloading ideas." 40

But which ideas? Since the readymades seem to stage a functional epoché, a decreative regaining of potentiality through displacement from their usual actualization, they already border upon that down-scaling of spatial dimensionality-the shift from appearance to so-called apparition-that operates on several levels in the Large Glass. Like many other avant-garde artists of his youth, Duchamp wished for art to participate in the supra-sensuous 4-dimensional reality that was recently proposed by scientists, mathematicians, and occultists, but as a specialty he believed this could only happen through a highly indirect, almost inverse route-the spatial version of the "shrink to expand" principle. Contrary to the Cubist and Futurist desire of visually upscaling objects to a 4-dimensional space, Duchamp opted for an antiretinal down-scaling from 3 to 2 , or perhaps rather 2.5 dimensions. Hereby, he imagined that objects would be cleansed of their more specific 3-dimensional contexts and thereby become moulds, apparitions, for a larger range of possible 3-dimensional casts, ultimately securing a better access to the desired 4-dimensional universe. Although Duchamp never specifies and apparently was not fully conscious of it, such spatial down-scaling from $n$ to $n-1$ dimensions, followed by a broader range of spatial up-scalings to something like $n+1$ dimensions, was structurally equivalent to the functional epoché of the readymades, their semiological freezing, followed by a broader range of possible actualizations.

\section{ALCHEMICAL STRIPPING BARE}

A powerful link between Duchamp's interests in epoché and multidimensional mediation is already provided by the alchemical imagery alluded to in the seemingly cryptic title of the Large Glass. The notion of stripping bare the Bride is undoubtedly a reference to that neo-alchemical universe which was part of speculative science around 1900 and some of whose key figures, including queens, brides, and virgins, find echoes in the proto-surrealist universe of Alfred Jarry. ${ }^{41}$ The epoché of the readymades, the business of deactualizing already functional gadgets in order to gain potentiality, is thus equivalent to alchemy's fundamental procedure: first purifying already existing dull materials into a more virginal state, the so-called prima materia, and then, from this re-opened potentiality, proceeding towards the production of gold. Fountain's transformation of a lowly urinal to art, piss to gold, Armut (R. Mutt) to riche art (Richard), would incarnate the most graspable 
example of Duchamp's use of this alchemical U-turn. And this is only deepened through the alleged status of Fountain as a signifier for the female organ, whose marital bonds to conventional ideas are loosened through it being wrecked of its usual context.

The process of alchemical restoration to prima materia was sometimes compared to the removal of clothes, indeed at times with the stripping bare of a bride. John Moffitt, for instance, draws attention to Basile Valentin's Die zwölf Schlüssel (1599), which describes how a virgin preparing for a marriage "is gloriously decked out in a variety of splendid and costly garments," from which she is later stripped in order to unite with her groom.42 As Linda Dalrymple Henderson has demonstrated, this source was most likely known in Duchamp's original milieu, the Puteaux circle of Cubists, since the head of the Societé Alchimique de France, the widely-read Jollivet Castelot, referred to it in his 1909 La Synthèse $d$ 'Or and further saw this procedure re-actualized in new physics, in which it is similarly "necessary to strip each metal of its particular individual properties, restoring it to the state of prime matter." 43

What is particular to Duchamp's stripping bare of the Bride, is that it is not performed by a faithful husband but by a whole horde of un-married Bachelors whose goal, as we saw earlier in connection to Fountain, is to deconstruct the locked marriages of ideas to matter. Moreover, as is indicated by the peculiar "her," these Bachelors are a sort of property of the Bride, and since the title's last enigmatic word, Even, strengthens the autonomy of the Bride-the French "même" a pun on "even," "she loves me" and especially "self"-the stripping is probably ultimately instigated by the Bride as the motor of the whole apparatus. In a similar fashion, it is the naked woman who has taken over the illuminating gas in Duchamp's last work, the peephole installation Étant donnés (1946-66) (Fig. 2.4).

\section{MEDIATING 4-DIMENSIONAL SPACE}

By stripping bare the Bride, then, taking away her actualized particularities, the Bachelors aim to make her like themselves, restoring her status as a free radical. Translated into spatial terms, the reason for this desire is that even the Bride's Cubo-Futurist dynamic space cannot depict 4-dimensional space directly. As Linda Dalrymple Henderson has amply demonstrated, although Duchamp was closely involved with that all-pervasive new discovery of the early twentieth century, 4-dimensional space, in contrast to the Cubists and Futurists, he became frustrated with art's inability to portray this space through the direct appeal to sensesthat is, in a retinal way. ${ }^{44}$ Rather than fulfilling Henri Bergson's 
ideal of art as recreating that organic spatio-temporal continuity which Bergson named the durée, the Bride has to approach this space through a montage of fragmented 2-dimensional projections of 3-dimensional space. This is the genealogy from chronophotography and film that the Italian Futurist Umberto Boccioni had to refuse in order to keep his version of Futurist dynamism, unique forms of continuity in space, intact in an allegedly nonmeasured, non-interrupted 4-dimensional space. ${ }^{45}$

In contrast, Duchamp insisted on photography as a master metaphor for both the access to the Bride and, as we shall see, the epoché of the readymades. Duchamp saw similarities between the down-scaling of photography from 3 to 2 dimensions and our everyday lives as 3-dimensional projections from an unseen 4-dimensional reality. Updating the way Plato's world of ideas exists in some intellectual realm that casts fainter shadows into the world of phenomena, Duchamp alludes in his notes to a world in which the infinitely rich supra-sensuous 4-dimensional reality casts myriads of 3-dimensional shadows, or projections, into our world of sensuous impressions. For in accordance with Duchamp's skeptical world view, the real 4-D world is infinitely larger than the 3-dimensional impressions we encounter through our accidental habits conditioned by our limited cognitive and sensuous capabilities. And since each of our experienced objects could be a 3-dimensional projection from a number of different 4-dimensional objects, obtaining better access to these objects and their alternative projective patterns would extend the amount of possible developmental paths in the 3-dimensional world. As Duchamp phrases it: "In Time the same object is not the same after a 1 second interval." 46

Inspired by his readings on the fourth dimension by writers such as the mathematician Henri Poincaré and his popularizer, the artillery officer and mathematician Esprit Pascal Jouffret, Duchamp found a key to the 4-dimensional world in what he termed "elementary parallelism." 47 Like a 3-dimensional cube is constructed from a parallel transformation of a simple 2-dimensional plane, so a 4-dimensional object will be constructed by multiplication of a simple 3-dimensional object. As he puts it in the White Box (À l'Infinitif, 1966), it is a "Sort of parallel multiplication of the n-dim'l continuum, to form the $\mathrm{n}+1$ dim'l continuum." 48 However, in our everyday experience, we are locked in one interpretation of the 3-dimensional space instead of being opened towards the many unknown 4-dimensional objects of which this space is in fact a projection. As Duchamp describes it: "All these past and future fractions thus coexist in a present which is really no longer 
what one usually calls the instant present, but a sort of present of multiple extensions (étendues)_”. ${ }^{49}$ Therefore, in order to generate material for more parallel multiplications than the ones we are traversing already, bits from the 3-dimensional world must be extracted and prepared for further parallel multiplication that may open our world for new possibilities.

Duchamp found the main model for such an extraction in photographic and cinematic freezing, which extracts frames of reality while lowering their dimensionality, moving each of them from 3 to 2 dimensions and thereby paving the way for a larger number of 3-dimensional objects, of which each may be a projection. In contrast to Cubist and Futurist strategies of multiplying 2-dimensional projections of 3-dimensional fragments in order to directly visualize 4-dimensional qualities, Duchamp from 1911 onwards opted for what he termed de-multiplication, stressing the individual frames of cinematic movement instead of synthesizing them. ${ }^{50}$ Whereas Cubo-Futurist montages still assembled aspects of integrated spatio-temporal transformations, Duchamp broke up montages to such a degree that each fragment was no longer allied with the other fragments. Rather, each fragment generated its own world of extended possibilities.

Duchamp seemed to be aware from early on that this was a process of stripping bare, of cleaning of particularities, both in terms of spatiality and the gaining of potentiality. For instance, just as individual sights of the same woman are de-multiplied and singled out to separate fragments that are then semitransparently over-layered in his painting Dulcinea (1911), the woman seems to be gradually divested of her clothing. ${ }^{51}$ Likewise, although more futuristically dynamic in appearance, even the Nude Descending a Staircase (1912) (cp. Fig. 4.1) may allude to such a process of combined spatio-particular scaling down, with the stripped appearance resulting from descending a staircase of both spatiality and actualization.

After Duchamp's break with painting in 1912, Cubo-Futurist dynamic space could thus only be retained as part of more reflected visual arguments of translations, "common factors" between different artistic strategies for approaching 4-dimensional spaceapart from the Large Glass that of the $T u$ m', Duchamp's final painting from 1918. Translated into the different dimensional realms of the Large Glass, the stripping bare of the Bride therefore amounts to taking away her still compromised retinal surroundings, her incomplete 4-dimensionality. Indeed, the transparent glass seems to have eaten away-stripped bare-large portions of those 
former represented 4-dimensional surroundings with which Duchamp enwrapped figures in his earlier paintings, for instance The Passage from Virgin to Bride (1912).

This skeletal appearance and vacuity of retinal surroundings is then pre-given in the mechanical Bachelor Apparatus in the lower part of the Glass, whose 3-dimensional perspective has become strictly object oriented. The objects themselves thus hover freely in the Glass's transparent mediations of the actual physical milieu of the work, having been erased beforehand from any represented backgrounds. As Duchamp put it in the interview with Francis Roberts in 1963:

The main point is the subject, the figure. It needs no reference. It is not in relation. All that background on the canvas that had to be thought about, tactile space like wallpaper, all that garbage, I wanted to sweep it away. With the glass you can concentrate on the figure if you want and you can change the background if you want by moving the glass. 52

This sweeping away of all spatial garbage, performed by the work's primal innovation, its transparent glass, is thus a powerful visual metaphor, if not a concrete indexical manifestation of that tabula rasa of regained potentiality, the matter stripped bare, which prima materia represented to the alchemists. As Duchamp stresses, transparency not only erases the pre-given represented perspective, whether 3-dimensional or quasi-4-dimensional and tactile (spatial down-scaling to $\mathrm{n}-1$ dimensions, and according raising of potentiality); it also opens the figures in the same moment towards a flexibility of contingent perspectives, any momentary viewpoint determined by the location, the changed background, in the actual physical surroundings (spatial upscaling to $n+1$ dimensions). This multitude of possible perspectives is what adds up to the 4-dimensional continuum. Duchamp specifies in a note: "Make a painting on glass so that it has neither front nor back, neither top nor bottom. (-to use probably as a three-dimensional physical medium in a 4 -dimensional perspective).”53

\section{THE READYMADES THROUGH THE LOOKING-GLASS}

What now prepares the ground for the readymades in this terrain of spatial erasing more specifically, is Duchamp's speculations of spatial down-scaling from $\mathrm{n}$ to $\mathrm{n}-1$ dimensions as a movement from appearance to apparition-apparition being a mould, a negative or a cliché, from which new appearances may be cast. 
Apparently, his trigger was again Gsell's interviews with Rodin, although this time he adopted a rather more antagonistic approach. Remember that Duchamp upon his arrival in New York found "the idea of destructing old buildings, old souvenirs [...] quite alright.” He therefore seemed especially receptive to Rodin's appalled statement of real estate buyers' destruction of the neighboring Château d'Issy in 1910, already ruined during the Paris Commune of 1871: "It affected me as much as though these criminals had disemboweled a fair virgin [éventré une belle vierge] before my eyes!" ${ }^{4}$ Isn't the stripping bare of the Bride by a horde of Bachelors, a dimensional down-scaling that even bares her inner parts, strikingly close to such a disembowelment of a beautiful virgin by several wrongdoers? Whereas Rodin had already resuscitated the soon to be disemboweled virgin, building completely anew the portal of the ruined castle in his garden at Meudon from 1907-08, Duchamp created a portal from the disemboweled virgin herself. More precisely, through the very act of Bachelors' stripping bare a Bride, a virgin was reobtained.55

Duchamp was further triggered by the mention in Gsell's interviews of Rodin denigrating sculptural casts as being less true and more superficial than his own sculpture that captures the inner truth of nature through spirit and emotion. ${ }^{56}$ In parallel with Bergson, Rodin also versed this criticism against photographs that "petrified" movements in contrast to art's ability to capture the "progressive development of movement." 57

Like the statement of the disemboweled virgin, these criticisms of casts and photographs must have been fuel for the discretely contentious Duchamp, who immediately afterwards, in 1912, turned towards his alchemical studies of nudes, virgins, and brides, and after that toward radical anti-retinalism, industrial massproduction, photographic clichés, and unemotional methods of precision painting. More specifically, apparition would join together in one concept Rodin's hate objects, the unemotionally accurate photograph and the sculptural cast, through foregrounding and fusing the clichés behind both the negative and the mould into one master figure: the apparition. Instead of a spiritual genius tracing itself in one unique appearance, we now have a mechanical cliché, the apparition, with heightened potentiality for generating a swarm of new appearances.

Judging from a remark in the Green Box that, "In general, the picture is the apparition of an appearance [...]," 58 one might think that the apparition is a simple down-scaling from 3 to 2 dimensions. ${ }^{59}$ But the 2 dimensions get into trouble when Duchamp 
also combines the apparition with the mould for 3-dimensional things and, accordingly, a more spatial preservation. The apparition hereby becomes a more comprehensive photographic mould or negative, not only able to reproduce positive casts, or prints in 2-dimensions, but to re-construct a full 3-dimensional appearance of the object, or rather a set of appearances of the object, of which it is a lower-dimensional image. Since it is not simply flat, I would claim that this lower-dimensional surface appearance, the apparition, must be located somewhere between 3 and 2 dimensions, for instance in 2.5 dimensions.

Isn't it tempting to consider the epoché of the readymades, their gaining of potentiality through being stripped bare of their actualization, as compatible with such a movement from appearance to apparition? The readymades thus emerge as objects of apparition, industrially manufactured 3-dimensional appearances that have been down-scaled to a slightly lower 2.5-dimensional state, in which they can act as moulds or negatives for a broader range of casts-interpretations occasioned by new contexts. Although not entering the discussion of any further interpretative consequences, Craig Adcock, in his analysis of Duchamp's geometrical speculations, already suggested the readymades as 3-dimensional snapshots becoming mould-like clichés: "Duchamp's ready-mades can be interpreted as individual 'de-multiplications' of potentially infinite 'continua' of readymades coming off mass-production lines.” 60

If the necessary shedding of particularities in order to reach apparition seems to make the readymades less material than their fully fleshed siblings, the actualized appearances, this is confirmed by the strikingly ethereal way the readymades are often presented-as if they mediate across different localities and spaces. In several photographs from Duchamp's New York studio at 33 West 67th Street, the readymades seem to flicker between a number of realities. Take the post-processed photograph Bicycle Wheel and Trap in Duchamp's portable museum, Box in a Valise (1941) (Fig. 4.4). Here, the readymades join other pieces of furniture (two armchairs and some pillows) in being set apart from their purely photographic base through layers of manually highlighted colors. The Trap even appears as an exquisite black and white linear drawing. Through levitating indeterminately in the representation of 3-dimensional space, they enter a translocal multidimensional space in which they mediate between different reality levels.

This effect of translocation seems even to affect human beings who enter the swarm of readymades. In what appears as a double 
exposure, probably made by Duchamp himself, the now substantial yet fleeting appearance of hanging readymades (hat rack, snow shovel, urinal) counteracts that of a sitting but strikingly ghostlike, transparent male (Henri-Pierre Roché) (Fig. 1.1). Emphasizing that bodies too are becoming trans-spatial assemblages like the machines that surround them, the male figure is divided in two-the crossing legs obviously out of sync with the diminutive upper body. No wonder that, when apologizing for her co-responsibility for refusing Fountain from the Independents' exhibition in a letter to Duchamp, Katherine S. Dreier excused herself with her former belief that readymades only appeared in such "groups which were extremely original in their handling. I did not know that you had conceived of single objects.”61 In Duchampian terms, Dreier saw the readymades as multiplied Cubism-wise and was stunned of the consequential demultiplication of the swarm into just one readymade.

This projective side of the readymades culminates in what Duchamp termed his "inventory of all [his] preceding works," the Tu m' of 1918. Here, "real” phenomena like a bottle brush and three safety pins mingle with diverse projective images, including the cast shadows from several readymades: the Bicycle Wheel (Fig. 5.4), the Hat Rack (Fig. 5.5) and a later lost or never-existing corkscrew. ${ }^{62}$ When Duchamp in a note from the Green Box announces the intention to produce such a picture using a "shadow [ombre portée] cast by 2, 3, 4, Readymades. 'brought together', he not only states the idea of a composite shadow but also alludes to the ability of the readymades to mediate and oscillate between the $2 \mathrm{nd}$, 3rd and 4 th dimensions. ${ }^{63}$ To emphasize how ambivalently the readymades hover between such dimensions, Duchamp informed Arturo Schwarz as late as 1968 that "One may consider the shadow of the corkscrew as the Readymade rather than the corkscrew itself." [emphasis in Schwarz $]^{64}$ Actually, this confusing game with projections is in full correspondence with my general reading if the shadow is read as a 2.5-dimensional apparition derived from the 3-dimensional appearance of the corkscrew. This reading is confirmed in the contemporary photograph directly inscribed ombres portées, 1917, N.Y. (in reality 1918), in which a bewildering mass of shadows cast from Hat Rack, Bicycle Wheel, and Sculpture for Travelling projects a similarly down-scaled dimensional world onto the studio wall.65

What strengthens this spatial interpretation of the readymades is Duchamp's notion of the infrathin, which he probably derived from the earlier mentioned popularizer of Poincaré, Esprit Jouffret. According to Jouffret's treatise, Traité élémentaire de géométrie en quatre dimensions (1903), from the point of view of the 
4-dimensional continuum, the étendue, the 3-dimensional space "forms an infinitely thin layer" (une couche infiniment mince)like the thickness of a 2-dimensional sheet of paper indicating its possibility of being extended into a 3-dimensional cube. ${ }^{66}$ Already in 3-dimensional space plans, lines and points may be considered insubstantial in themselves, "the separations stripped [dénuées] of all sorts of thickness and reality that one's thought sees between them" [Jouffret's italics] —an idea and phrasing pointing toward the stripping bare of spatial actualization met in both Bride and readymades. 67 In an interview from 1945, Duchamp declared: "I believe that through the infra-thin one may pass from the second to the third dimension." 68 Although the readymades move backwards in the process of their formation, recreating a mould through decreating one of its casts, Duchamp also extended the notion of infrathin to those more obvious moulds that preceded the later de-created casts: "The difference (dimensional) between 2 mass produced objects [from the same mould] is an infra thin when the maximum (?) precision is obtained." 69 Through a variety of massproduced replicas, the range of casts with infrathin differences expands. Becoming an apparition again, each ex-cast is thus overlayered with yet another infrathin difference.

That the infrathin, the downscaling of objects from appearance to apparition, ultimately concerns epoché, extension of potentiality, is also confirmed in Duchamp's notes: “The possible implying the becoming-the passage from one to the other takes place in the infra-thin." And in the preceding note on the same sheet: "The possible is an infra thin-The possibility of several tubes of color becoming a Seurat is the concrete 'explanation' ['l'explication'] of the possible as infra thin."70 In late statements, for instance in the interview with Roberts, Duchamp combines this possibility of paint tubes with the readymade: "So the painter really is making a Ready-made when he paints with a manufactured object that is called paints." 71 De-creating a urinal through establishing an apparition with an infrathin layer of expansive possibilities is thus equivalent to viewing a Seurat painting as a readymade-that is, as only one of several possibilities of the infrathin tubes of colour, whose potentiality is exactly re-exposed by terming the finished painting a readymade. Instead of creation ex nihilo, formation of virginal paint, the Seurat is judged as de-creation, removing actualization from tube paint as already produced.

Moreover, the connection between the readymades and Duchamp's speculations on spatial downscaling, including its exploration in the Large Glass, is strengthened by his linking of 
photography and allegory. Here, photographical downscaling, the freezing of things into lower-than-3-dimensional apparitions, becomes equivalent to their encapsulation in frames or auras of concepts. Take Duchamp's remark in the Green Box:

\section{Specifications for "Readymades."}

By planning for a moment to come (on such a day, such a date such a minute), "to inscribe a readymade"

- The readymade can later be looked for.

- (with all kinds of delays)

The important thing then is just this matter of timing [horlogisme], this snapshot effect [instantane], like a speech delivered on no matter what occasion but at such and such an hour. It is a kind of rendezvous.

- Naturally inscribe that date, hour, minute, on the readymade as information. also the serial characteristic of the readymade. 72

This passage invokes the creation of the readymade as a preplanned inscription in time, a rendezvous, in which a certain chosen thing receives a symbolic mark according to preset temporary coordinates. As Jean Clair has demonstrated, the coming-into-being of the readymades in such a temporal bracketing out of a real piece of matter points toward photography, as does its creation through choice rather than making. ${ }^{73}$ The idea of a photography capable of a material intrusion was already alluded to in Jarry's The Supermale, where chemistry is called "a sort of photography, only you can never frame its prints." 74 And when The Blind Man defines the new thought created for Fountain as its new title and point of view, this photographic thinking around the readymades is furthered. Even the inscription, compared to giving a statement, is part of the business of choice and later reinterpretation of photography. Like Walter Benjamin remarks in his Little History of Photography (1931), as the camera gets ever smaller, it snatches secret and versatile images whose shock in the viewer brings his ability to associate to a halt:

This is where inscription must come into play, which includes the photography of the literarization of the conditions of life, and without which all photographic construction must remain arrested in the approximate. [...] Won't inscription become the most important part of the photograph?75 
Thus, by inscribing the mass-produced gadgets anew, photographically freezing them through lamination in a disruptive semiological aura, Duchamp liberates them from the crippling habits of bourgeois culture, which are themselves no more than a freezing of the accidental, although performed daily as if they were anything but. Moving from Duchamp's programmatic notes to his actual readymades, the inscription could be understood as both the act of withdrawing the utilitarian object from its usual context and the occasional act of inscribing it, as is seen in the case of Fountain, Comb, and, presumably, the snow shovel. As Duchamp explained in his talk "Apropos of 'Readymades'” in 1961, the "sentence" he inscribed, "instead of describing the object like a title was meant to carry the mind of the spectator toward other regions more verbal." 76 That is, again, inserting the object in a semiological frame.

Such an inscriptive frame, mediating between icon and symbol, photographic freezing, and aura of semiological concepts, is actually visualized in the Large Glass itself, namely in what Duchamp, in his notes, terms the "Top Inscription" or "Milky Way." It is in the three versatile window frames of this cloud-like formation, the wind-blown "Draft Pistons," that the Bride would perform her series of so-called "Cinematic Blossomings"-the only way she reveals herself to the Bachelors. To further stress the photographic nature of this “Top Inscription,” Duchamp originally wanted to transfer it to glass by photo-mechanical means-a procedure echoed in the way his first box of notes, the Box of 1914, was published in containers for photographic prints manufactured by Kodak. ${ }^{77}$ Hitherto, the "Top Inscription" has been seen exclusively as a communicative interface in which the Bachelors get an indirect access to the Bride; however, noticing the similarities between its semiological-photographic function and Duchamp's photographic procedure for inscribing a readymade, it must be viewed as a main instrument in Duchamp's movement into conceptual art. Echoing the strategy for the readymades, this figure converts in one go retinal window to semiological frame, photographic freezing to inscription. In this amorphous cloud penetrated by its three soft-blowing frames of looking-glass, we have an early visualization of that art philosophical dazzle, the aura of concepts, that Arthur C. Danto sees as a fundamental condition for posthistorical art. ${ }^{78}$

This allegorical tendency, dissociating the ideas from the things they frame as a looking-glass, is echoed on the very level of the presentation of the Large Glass itself, which thereby becomes an 
enlargement of the draft pistons. For from early on, Duchamp removed from public eye the concepts explaining the cryptic iconography of the Glass. Their publication in set after set of delayed and isolated notes created a philosophical dazzle around the Glass at the same time as this detachment emphasized their ideologically unmarried state, their freedom from the material core of the work. Instead, the allegorical separation between concepts and things stressed the impact of the art co-efficient, the disjunction between what the artist intended and what could be later perceived by the spectator.

De-multiplication, apparition, ombre portée, infrathin, snapshot, inscription, allegory-all then concern a spatial down-scaling, a stripping bare of 3-dimensional particularities that is compatible with that decreation of fabricated things, epoché, which is going on in the readymades. Shrunk to alchemical prima materia, lowerdimensional moulds, with an accordingly re-gained potentiality, the readymades may, with delay, expand into a myriad of higherdimensional appearances and thereby approach the invisible 4-dimensional world. 
1 Marcel Duchamp, "Where do we go from here," trans. Ellen Meakins, published in paper from a seminar with the same title at Philadelphia Museum College of Art, March 1961, facsimile of French manuscript (dated, probably incorrectly, 1960), in Studio International 189, no. 973 (Spring 1975): 28.

2 Hal Foster, The Return of the Real: The Avant-Garde at the End of the Century (Cambridge (MA) and London: MIT Press, 1996), x, xii, 13.

3 Calvin Tompkins, Marcel Duchamp: The Afternoon Interviews [1964] (New York: Badlands, 2013), 29.

4 Jochen Schulte-Sasse, "Foreword: Theory of Modernism vs. Theory of the Avant-Garde," in Peter Bürger, Theory of the Avant-Garde [1974, 1980], trans. Michael Shaw (Manchester: Manchester University Press, 1984), vii-xIvii.

5 Thierry de Duve, Kant after Duchamp (Cambridge (MA) and London: MIT Press, 1996), 304.

6 Thomas McEvilley, "empyrrhical thinking (and why kant can't)," Artforum 27 (October 1988): 120-27.

7 Arturo Schwarz, The Complete Works of Marcel Duchamp, vol. 1 (New York: Delano Greenridge Editions, 3rd ed., 1997), 33. See also Eric Cameron, "Given," in ed. Thierry de Duve, The Definitively Unfinished Marcel Duchamp (Cambridge (MA): MIT Press, 1993), 1-29, here 5-8.

8 Diogenes Laërtius, "Pyrrho," in Lives and Opinions of Eminent Philosophers, trans. C.D, Yonge (London: Henry G. Bohn, 1853), VI, 404.

9 Ibid., IX, 410.

10 Calvin Tomkins, The Bride and the Bachelors: The Heretical Courtship in Modern Art [1962] (London: Weidenfeld and Nicolson, 1965), 34; see also Tomkins, Duchamp: The Afternoon Interviews, 84-85.

11 Diogenes Laërtius, "Pyrrho," VIII, 408.

12 Ibid., VIII, 407.

13 Francis Roberts, "I Propose to Strain the Laws of Physics," Art News 67, no. 8 (December 1968): 46-47 and 62-64.

14 Schwarz, The Complete Works, vol. 1, 33; Octavio Paz, Marcel Duchamp: Appearance Stripped Bare [1976], trans. Rachel Phillips and John Gardner (NewYork: Viking Press, 1978), 22.

15 Herman Melville, Bartleby, The Scrivener. A Story of Wall-Street, in Putnam's Monthly Magazine, NovemberDecember 1853, 546-615, reprinted in ed. Howard P. Vincent, Melville Annual 1965: A Symposium: Bartleby the Scrivener (Kent (OH): Kent State University Press, 1966).

16 I have not been able to recover this source.

17 Giorgio Agamben, "Bartleby, or On Contingency" [1993], in Potentialities: Collected Essays in Philosophy (Stanford: Stanford University Press, 1999), 243-71, here 270. On monotheistic creation ex nihilo: ibid., 251-52.

18 Marcel Duchamp, "The Creative Act," presented at the Convention of the American Federation of Arts, Houston, April 1957, in Robert Lebel, Marcel Duchamp, trans. George Heard Hamilton (London: Trianon Press, 1959), 77-78, here 78. I thank Thierry de Duve for exposing this similarity.

19 Enrique Vila-Matas, Bartleby and Co. [2000], trans. Jonathan Dunne (London: Vintage 2005), 56-60.

20 Tomkins, Duchamp: The Afternoon Interviews, 87.
21 Dora Vallier, "La vie fait l'oeuvre de Fernand Léger: Propos de l'artiste recueillis," Cahiers d'Art 29 (1954): 133-173, here 140. My translation.

22 Interview with Bessie Breuer, New York Tribune, September 12, 1915, and Arts and Decoration, September, 1915, cited after Calvin Tomkins, Duchamp: A Biography (New York: Henry Holt and Company, 1996), 152.

23 Pierre Cabanne, Dialogues with Marcel Duchamp [1968] (London: Thames and Hudson, 1971), 39.

24 Tomkins, Duchamp: A Biography, 162.

25 Remy de Gourmont, "La dissociation des idées," in Gourmont, La Culture des Idées (Paris: Société du Mercure de France, 1900), 73-110.

26 Michel Sanouillet and Elmer Peterson (eds.), Salt Seller: The Essential Writings of Marcel Duchamp (London: Thames and Hudson, 1975), 23.

27 From an interview with Lawrence D. Steefel, Jr. for his PhD dissertation, quoted in Steefel, The Position of Duchamp's Glass in the Development of His Art [1960] (New York and London: Garland Publishing Inc., 1977), 312, note 39.

28 Minneapolis, Regis Collection; see Dieter Scholz (ed.), Marsden Hartley-Die deutschen Bilder 1913-15 (Cologne: Verlag der Buchhandlung Walther König, 2014), 73.

29 See Scholz, Marsden Hartley, 2, 67, 72, 74, 99-102; and Patricia McDonnell, “'Essentially Masculine': Marsden Hartley, Gay Identity, and Wilhelmine German Military," Art Journal 56, no. 2 (Summer 1997): 62-68.

30 Alfred Jarry, The Supermale [1902], trans. Ralph Gladstone and Barbara Wright (Cambridge: Exact Change, 1999), 39.

31 Jarry, The Supermale, 75. The relevance of these passages for Duchamp has apparently not been noticed before.

32 Schwarz observes a "multiplaction of the phalluslike spikes" and parallels Duchamp's bachelor status to the fact that the dryer never received its bottles, The Complete Works of Marcel Duchamp, vol. 1, 189.

33 Reproduced in Jean Clair, Duchamp et la photographie: Essai d'analyse d'un primat technique sur le développement d'une oeuvre (Paris: Éditions du Chêne, 1977), 63.

34 Auguste Rodin, Art [1911], trans. Romilly Fedden (Boston: Small, Maynard \& Company Publishers, 1912), 232; original in Auguste Rodin, L'Art: Entretiens réunis par Paul Gsell (Paris: Bernard Grasset, 1911), 296.

35 Rodin, Art, 233; original in Rodin, L'Art, 297-298.

36 Slightly revised version of Rodin, Art, 231; original in Rodin, L'Art, 296.

37 Martin Heidegger, Being and Time [1927], trans. John McQuarrie and Edward Robinson (Oxford and Cambridge (MA): Blackwell, 2001), §§15-16, 95-107.

38 Martin Heidegger, "The Origin of the Work of Art," in Heidegger, Poetry, Language, Thought [1936], trans. Albert Hofstadter (New York: Harper Collins, 1971), 15-86. In the only other comparison of Duchamp and Heidegger I have come across, the author does not move much further than this observation; see Anita Alkhas, "Heidegger in plain sight: 'The Origin of the Work of Art' and Marcel Duchamp," Journal of Philosophy: A Cross 
Disciplinary Inquiry 5, no. 12 (March 2010): 1-13.

39 Martin Heidegger, "The Question Concerning Technology," in Heidegger, The Question Concerning Technology and other essays [1954], trans. William Lovitt (New York: Harper Torchbook, 1977), 3-35.

40 Otto Hahn, "Passport No. G255300," Art and Artists 1 (July 1966): 6-11, here 10.

41 Jarry, The Supermale, passim; Linda Dalrymple Henderson, Duchamp in Context: Science and Technology in the Large Glass and Related Works (Princeton: Princeton University Press, 1998), 49. For an overview of earlier treatments of Duchamp's relation to alchemy, see Dieter Daniels, Duchamp und die Anderen: Der Modellfall einer künstlerischen Wirkungsgeschichte der Moderne (Cologne: DuMont Buchverlag, 1992), 238-57.

42 John F. Moffitt, "Marcel Duchamp: Alchemist of the Avant-Garde," in ed. Edward Weisberger, The Spiritual in Art: Abstract Painting 1890-1915, exhibition catalogue. Los Angeles County Museum of Art Nov. 23, 1986March 8, 1987 (Los Angeles: Los Angeles County Museum of Art and New York: Abbeville Press, 1986), 257-71, here 266.

43 Henderson, Duchamp in Context, 26, 231-32. A further source for Duchamp was probably the chemist Albert Poisson, Théories et symbols des alchimistes: Le GrandOeuvre, suivi d'un essai sur la bibliographie alchimique du XIXe siècle (Paris: Charcornac, 1891); see Moffitt, 266. A facsimile manuscript of La Philosophe Solidonius (c. 1800) with a watercolor drawing, in which two males strip a woman naked as illustration of the stripping to primal matter, was owned by Poisson; see Henderson, Duchamp in Context, 231-32, and M.E. Warlick, "Fluctuating Identities: Gender Reversals in Alchemical Imagery," in ed. Jacob Wamberg, Art \& Alchemy (Copenhagen: Museum Tusculanum Press, 2006), 10328, here 108-10, with illustration 109.

44 Henderson, The Fourth Dimension and Non-Euclidean Geometry in Modern Art (Princeton: Princeton University Press, 1983), 117-63; Henderson, Duchamp in Context, 80-85.

45 Henderson, "Boccioni's Italian Futurist Critique of Cubism's Fourth Dimension," in The Fourth Dimension, 110-16, especially 110-11.

46 Marcel Duchamp, Notes, ed. and trans. Paul Matisse (Paris: Centre National d'Art et de Culture Georges Pompidou, 1980), no. 8.

47 Craig E. Adcock, Marcel Duchamp's Notes from the Large Glass: An N-Dimensional Analysis (Ann Arbor: Umi Research Press, 1981), 139-45.

48 Salt Seller, 92.

49 Duchamp, Notes, no. 135.

50 Adcock, Marcel Duchamp's Notes from the Large Glass, 143-46; Clair, Duchamp et la photographie, 30.

51 Clair, Duchamp et la photographie, 30, sees the stripping related to de-multiplication but not to gain of potentiality; Schwarz, The Complete Works, vol. 1, 107, remarks the stripping alone.

52 Robert, "I Propose to Strain the Laws of Physics," 46.

53 Duchamp, Notes, no. 67.

54 Slightly moderated version of Rodin, Art, 13; original in Rodin, L'Art, 13.
55 On Château d'Issy, consult fr.wikipedia.org.

56 Rodin, Art, 31-34; original in Rodin, L'Art, 30-35.

57 Rodin, Art, 73-77; original in Rodin, L'Art, 84-89. Although Rodin's so-called "Testament" was seemingly first published in a version of Gsell's L'Art from 1917, see http://www.litteratureaudio.com/livres-audio-gratuits$\mathrm{mp3} /$ tag/auguste-rodin, it nicely sums up his views: "Be true, young people. But this does not mean: be flatly accurate. There is a low accuracy: that of photography and casting. Art only begins with the inner truth. Make all your shapes, all your colours reflect feelings." See also Clair, Duchamp et la photographie, 104.

58 Salt Seller, 30.

59 Ibid., 84-85; Henderson, The Fourth Dimension, 138.

60 Adcock, Marcel Duchamp's Notes from the Large Glass, 158-162, citation 158.

61 William A. Camfield, Marcel Duchamp: Fountain, intr. Walter Hopps (Houston: Houston Fine Arts Press, 1989), 30-31.

62 Schwarz, The Complete Works, vol. 2, 658.

63 Salt Seller, 33; Marcel Duchamp, Duchamp du signe suivi de Notes, eds. Michel Sanouillet and Paul Matisse, revised by Anne Sanouillet and Paul B. Franklin (Paris: Flammarion, 1994, 1975), 69; Henderson, The Fourth Dimension, 158. See also Salt Seller, 72.

64 Schwarz, The Complete Works, vol. 2, 657.

65 Ibid., no. $357,660$.

66 Esprit Jouffret, Traité élémentaire de géométrie en quatre dimensions (Paris: Gauthier-Villars, 1903), xxviii; Henderson The Fourth Dimension, 162-63.

67 Jouffret, Traité, viii.

68 Interview with Denis de Rougemont, "Marcel Duchamp, mine de rien," Preuves. Cahiers mensuels du Congrés pour la liberté de la Culture, no. 204 (February 1968): 4347, here cited from Clair, Duchamp et la photographie, 96.

69 Duchamp, Notes, no. 18. On the infrathin in relation to aesthetic judgment, see Thierry de Duve, Pictorial Nominalism: On Marcel Duchamp's Passage from Painting to the Readymade [1984], trans. Dana Polan with the author (Minneapolis and Oxford: University of Minnesota Press, 1991), 159-163.

70 Duchamp, Notes, no. 1.

71 Roberts, "I Propose to Strain the Laws of Physics," 47. See also the talk delivered at the Museum of Modern Art, New York, on October 19, 1961, "Apropos of 'Readymades'," reprinted in Salt Seller, 141-142, here 142.

72 The Green Box, Du signe, 68; Salt Seller, 32.

73 Clair, Duchamp et la photographie.

74 Jarry, The Supermale, 35.

75 Walter Benjamin, "Little History of Photography," in eds. Michael W. Jennings, Howard Eiland, and Gary Smith, Walter Benjamin: Selected Writings, Vol. 2: 1927-1934 [1931], trans. Rodney Livingstone et al (Cambridge and London: Belknap Press of Harvard University Press, 1999), 507-30, here 527.

76 Duchamp, “Apropos of Readymades," in Salt Seller, 141.

77 Henderson, Duchamp in Context, 80-81; Schwarz, The Complete Works, vol. 2, 598-603.

78 Arthur C. Danto, "The End of Art," in Danto, The Philosophical Disenfranchisement of Art (New York: Columbia University Pres, 1986), 111. 